\title{
Entropy for Business Failure Prediction: An Improved Prediction Model for the Construction Industry
}

\author{
Jay Bal, ${ }^{1}$ Yen Cheung, ${ }^{2}$ and Hsu-Che $\mathrm{Wu}^{3}$ \\ ${ }^{1}$ International Digital Laboratory, University of Warwick, Coventry CV4 7AL, UK \\ ${ }^{2}$ Clayton School of IT, Monash University, Melbourne, Vic 3800, Australia \\ ${ }^{3}$ Department of Accounting and Information Technology, National Chung Cheng University, 168 University Road, \\ Min-Hsiung, Chia-Yi County 621, Taiwan \\ Correspondence should be addressed to Jay Bal; jay.bal@warwick.ac.uk
}

Received 9 April 2013; Accepted 31 October 2013

Academic Editor: David Bulger

Copyright (C) 2013 Jay Bal et al. This is an open access article distributed under the Creative Commons Attribution License, which permits unrestricted use, distribution, and reproduction in any medium, provided the original work is properly cited.

This paper examines empirically the effectiveness of entropy measures derived from information theory combined with discriminant analysis in the prediction of construction business failure. Such failure in modern complex supply chains is an extremely disruptive force, and its likelihood is a key factor in the prequalification appraisal of contractors. The work described, using financial data from the Taiwanese construction industry, extends the classical methods by applying Shannon's information theory to improve their prediction ability and provides an alternative to newer artificial-intelligence-based approaches.

\section{Introduction}

Over the last 35 years, business failure prediction has become a major research domain especially with increased global business competition [1]. Business failure is an extremely disruptive force in the construction industry [2]. Kangari et al. [3] indicated that the construction industry in the USA has several unique characteristics that sharply distinguish it from other sectors of the economy. The bankruptcy rate within the American construction industry has been increasing in recent years and the USA has the highest percentage of construction company failures each year $[4,5]$. The construction industry is also a major industry in the UK and has the highest percentage of company failures each year $[6,7]$. Similarly, in Asian countries like Taiwan where there has been phenomenal growth in the last few decades, the construction sector also plays a major economic role.

Beaver [8] was one of the first researchers to study business failure prediction. He analysed financial ratios one by one to evaluate their predictive ability. He then developed their predictive abilities using cutoff scores to classify each company as either failed or nonfailed company. However, this classification technique uses one ratio at a time and conflicts arise when one ratio classifies the company as healthy whilst another detects distress. His work was followed by Altman's [9] model based on discriminant analysis and Ohlson's work [10] based on the use of logistic regression.

Like many other problems in science and engineering, popular machine learning techniques from the 1990s such as neural networks and genetic algorithms have also been applied to business problems such as bankruptcy or business distress detection $[11,12]$ with some successes. When qualitative data and uncertainties abound, these techniques are very useful indeed. However, techniques such as artificial neural networks require large datasets for training purposes and large models are often less easy to interpret [13]. Recent research trends in this area have also employed hybrid methodologies combining both machine learning techniques with the traditional statistical approach with some successes [13]. In this paper, the research methodology employs quantitative financial data as applied in previous research, but augmented using Shannon's information theory to better predict business distress. As shown in previous works, particularly in the construction industry (i.e., the sector addressed in this paper), the financial ratios are very important characteristics when modelling and detecting 
business distress [14]. Thus, despite a move towards machine learning techniques, traditional approaches such as the use of financial ratios enhanced with other methods such as Shannon's information theory can be as good as the machine learning approach. This paper describes how.

Dimitras et al. [14] noted that most studies on business failure models used three types of firms in their sample: manufacturing firms, a combination of manufacturing and retailing firms or firms from several industrial sectors. Kangari et al. [3] and Dimitras et al. [14] stressed that models developed for the manufacturing industry are inappropriate for a construction company due to market segmentation and industry structure differences. The financial condition of a company is a very important factor in determining contractor selection in the construction industry. Birrell [15] reported that financial stability is one of the most important criteria for evaluating the performance of general contractors. A number of other researchers have also commented on the issue as follows.

(i) Russell and Jaselskis [16] compiled a sample of 344 construction professionals taken from professional organizations in the US. They noted that financial stability is the most important decision parameter for public contracts. Financial condition and experience are the most important composite decision factors (CDF) for private contracts.

(ii) Holt et al. [17] presented the findings of a survey of 53 major UK construction organisations. This revealed that financial stability was probably the most important factor of all those considered.

(iii) Bubshait and Al-Gobali [18] stated that contractor experience and financial stability are essential criteria for prequalification in Saudi Arabia.

(iv) The results obtained by Russell [19] for contractor prequalification in the US show that the first two criteria (experience and financial stability) have the same ranking as in Saudi Arabia.

(v) Ng and Skitmore [20] used a postal questionnaire survey of 192 client consultant organizations in the UK. They investigated the divergence of prequalification criteria (PQC) adopted by different types of organizations. The results revealed that the most important $\mathrm{PQC}$ is financial stability in both private and government contracts.

(vi) Wong et al. [21] noted that "lowest price" is now not necessarily the UK construction clients' principal selection criterion. They also revealed that both maximum resource and financial capacity are in the top 3 project-specific criteria for public construction.

(vii) Topcu [22] investigated the ability to complete construction projects on time in the Turkish public sector; $70 \%$ of the ability was assigned to "financial status."

(viii) Pongpeng and Liston [23] presented a study aimed at developing a common set of criteria with weights of relative importance to evaluate contractor ability for government and private sectors in the Thai construction industry. A result from the survey showed that financial ratio is one of five most important criteria in the private sector.

This literature emphasises that financial status is an important issue in the construction industry. Furthermore, Dimitras et al. [14] identified that many business failure prediction models are based on the financial characteristics of firms in the form of financial ratios. Most of these models evaluate the available financial characteristics (financial ratios) of the firms studied. Kangari [2] suggested that overall industry indictors must also be monitored and trends analysed to determine swings in overall industry failure probabilities to better help determine the exceptions among companies.

1.1. Research Objectives. Hamer's [24, page 77] research findings showed that the decomposition information measure for financial statements has a power of discrimination with respect to failed and nonfailed firms but the predictive ability is less than that derived from financial ratios. The goal in this research is to appraise empirically the usefulness of information measures (derived from information theory) in the prediction of construction business failure. In this research, the model is based on a financial distress definition of failure, not a juridical (mostly bankruptcy) definition. It appears that researchers in the area have not considered using the information measures of financial ratios to analyse whether this could improve predictive ability. Previous research on this issue appears to be inadequate [25-30].

Our new method modifies discriminant analysis with information measures derived from financial ratios. The data set used to test the hypothesis was from Taiwanese construction companies. Using this data set helps compensate for the lack of studies in the time, location, and industry differences affecting business failure prediction. Therefore, the research presented in this paper attempts to bridge a gap in earlier studies. The objectives of this paper are

(i) to find effective financial ratios as discriminant variables for predicting construction companies failures;

(ii) to assess whether information measures derived from financial ratios with discriminant analysis can improve the prediction ability of business failure compared to just using information measures of financial ratios and financial ratios with discriminant analysis;

(iii) to assess the value of a practical model that is able to predict the failure of companies in the Taiwanese construction industry. For example, the proposed model can assist the local authorities in the selection of an approved list of constructors for competitive tendering.

1.2. Failure Prediction Methods. Researchers in the past decade have realized that failure does not happen suddenly. Usually, failure take years; therefore, it is necessary to develop an early warning model that can evaluate the strengths and weaknesses of the financial features of companies. A number 
TABLE 1: Summary of failure prediction methods.

\begin{tabular}{llll}
\hline & Author & Year & Method \\
\hline \multirow{3}{*}{ Early studies } & Tamari [31] & 1966 & Index of risk \\
& Beaver [8] & 1968 & Univariate analysis \\
& Altman [9] & 1968 & Multivariate analysis (discriminant analysis) \\
& Taffler and Tisshaw [32] & 1977 & Multivariate analysis (discriminant analysis) \\
& Mason and Harris [6] & 1979 & Multivariate analysis (discriminant analysis) \\
Construction-specific models & Abidali and Harris [33] & 1995 & Multivariate analysis (discriminant analysis) \\
& Russell and Jaselskis [16] & 1992 & Logit analysis \\
& Severson and Russell [34] & 1994 & Logit analysis \\
\hline \multirow{2}{*}{ Hybrid models } & Zavergen [35] & 1985 & Logit analysis and entropy \\
& Keasey and McGuinness [36] & 1990 & Logit analysis and entropy \\
\hline
\end{tabular}

of failure prediction models have been developed, based on various techniques. Financial ratio analysis is a very common approach to diagnose the financial strengths and weaknesses in any company. However, these methods are often not employed early enough to predict business failure [37]. The majority of business failure prediction studies are based on the original research of Beaver [8] and Altman [9]. Beaver had made the greatest contribution to univariate analysis. Beaver's analysis involved the use of a single financial ratio in his failure prediction model. The approach had been criticised because just using a single financial ratio is not a sufficiently reliable way to predict failure. Altman [9] performed a multivariate analysis of failure using discriminant analysis. The main idea of this analysis is to combine the information from several financial ratios into a linear discriminant function. Then, a discriminant score is computed and an optimal cutoff point is determined. A number of other studies have followed this methodology to predict business failure in different industries. Although they are all based on the original method devised by Altman, they are all different since financial reporting standards vary according to local conditions, there are different politicaleconomic interrelationships, and there is not a great deal of similarity between different industries.

Lev [38] investigated the use of decomposition measures (information measures) in the prediction of financial failure. Lev compared the decomposition measures of matched pairs of failed and nonfailed firms. Decomposition analysis is a measurement associated with information theory by Shannon [39]. The contribution from information theory is the use of an information measure (entropy) for the unevenness of a distribution of weights based on pragmatic considerations. Concepts from information theory normally belong to the area of communication engineering. This approach is generally neglected in the field of prediction methods. Lev [38] identified that there is some power of discrimination with respect to failed and nonfailed firms, up to as far as five years prior to failure. This result suggested that some information measures may be usefully incorporated into the models employed to predict financial failure.

It is generally believed that financial data constitutes the most significant and accessible element in monitoring the performance of a firm and in predicting the trend toward failure. Most business failure prediction models are based on financial data. Argenti [40, page 121] described the financial data values as "symptoms" of failure rather than "causes." This means that financial figures can be considered an indicator in predicting the possibility of failure. There have been numerous studies using statistical techniques to develop a combination of financial ratios which would predict business failure. The most popular are the classical statistical techniques especially multivariate discriminant models and logistic models. Table 1 summarises the key approaches, and Table 2 identifies the ratios used in these approaches.

\section{Information Decomposition Analysis Using Entropy Measures for Business Failure Prediction}

The main problem with both univariate and multivariate analysis models described in the previous section is that they are not dynamic in nature. Models including trend variables to improve the selected financial ratios without dynamic attributes are a step in the right direction $[6,33]$. This research explores the transformation of financial ratios to information decomposition measures using information theory. Information theory is primarily directed at defining and measuring the amount of information contained in a message. Information is defined in this context as a function of the two sets of probabilities: the one before the reception of the message and the other after it. Therefore, knowledge of the changes in the probabilities permits measurement of the amount of information contained in the message that induced these changes. Such transformation can adjust the data to be naturally dynamic. Then, accumulative dynamic information measures of financial ratios can be compared with static financial ratios model in terms of their failure prediction ability.

Previous studies of the decomposition measures for failure prediction are based on elements of financial statements (e.g., assets, liabilities, and equity). The findings from previous research show that decomposition measures for financial statements have the power of discrimination with respect to failed and nonfailed firms, but the predictive ability is less than that for financial ratios. However, researchers in the area 
TABLE 2: A summary of results from previous studies based on the financial factors taken into account by the study.

\begin{tabular}{|c|c|c|c|c|c|}
\hline & Beaver, $1968[8]$ & Altman, 1968 [9] & $\begin{array}{c}\text { Taffler and } \\
\text { Tisshaw, } 1977[32]\end{array}$ & $\begin{array}{c}\text { Mason and } \\
\text { Harris, } 1979[6]\end{array}$ & $\begin{array}{c}\text { Abidali and } \\
\text { Harris, } 1995[33]\end{array}$ \\
\hline \multicolumn{6}{|l|}{ Ratio: profitability } \\
\hline $\begin{array}{l}\text { Earnings before interest and tax/net } \\
\text { capital employed (net assets }+ \text { short-term } \\
\text { loan) }\end{array}$ & & & - & - & \\
\hline $\begin{array}{l}\text { Earnings before interest and tax/net } \\
\text { assets (total assets - current liabilities) }\end{array}$ & & & & - & \\
\hline $\begin{array}{l}\text { Earnings before interest and tax/Total } \\
\text { assets }\end{array}$ & & $\bullet$ & & & \\
\hline $\begin{array}{l}\text { After tax profit/net capital employed (net } \\
\text { assets + short-term loan) }\end{array}$ & & & & & $\bullet$ \\
\hline Retained earnings/total assets & & • & & & \\
\hline Net income/total assets & & $\cdot$ & & & \\
\hline \multicolumn{6}{|l|}{ Ratio: activity } \\
\hline Turnover/earnings before interest and tax & & & & & • \\
\hline Sales/total assets & & • & & & \\
\hline $\begin{array}{l}\text { Working capital (current assets - current } \\
\text { liabilities/total assets) }\end{array}$ & $\bullet$ & $\bullet$ & & & \\
\hline \multicolumn{6}{|l|}{ Ratio: liquidity } \\
\hline No credit interval & • & & • & & \\
\hline Log10 (day debtors) & & & & $\bullet$ & \\
\hline Short-term loan/earnings before & • & & & & \\
\hline $\begin{array}{l}\text { interest and tax } \\
\text { Debtors/creditors }\end{array}$ & & & & - & \\
\hline Current assets/total liability & & & $\bullet$ & & \\
\hline \multicolumn{6}{|l|}{ Ratio: financial leverage } \\
\hline Market value of equity/book value of debt & & - & & & \\
\hline Total debts/total asset & - & & & & \\
\hline Current liabilities/total asset & & & $\bullet$ & & \\
\hline Current liabilities/current asset & • & & & - & \\
\hline Cash flow/total debts & - & & & & \\
\hline $\begin{array}{l}\text { Current assets/net assets (total assets - } \\
\text { current liabilities) }\end{array}$ & & & & & - \\
\hline \multicolumn{6}{|l|}{ Ratio: trend measurement } \\
\hline Tax trend & & & & & $\bullet$ \\
\hline After tax profit trend & & & & & • \\
\hline Short-term loan trend & & & & & - \\
\hline Creditors trend & & & & $\bullet$ & \\
\hline \multicolumn{6}{|l|}{$\begin{array}{l}\text { Total discriminator variables in } \\
\text { multivariate analysis model }\end{array}$} \\
\hline $\begin{array}{l}\text { Total discriminator variables in } \\
\text { multivariate analysis model }\end{array}$ & & 5 & 4 & 6 & 7 \\
\hline
\end{tabular}

appear to have not considered using the information measures of financial ratios to analyse whether that could improve predictive ability. Moreover, both univariate analysis and the multivariate discriminant analysis model are not dynamic in nature. Thus, the focus of this new work was to explore combining discriminant analysis with the information measures of financial ratios in order to address omission in the previous work. Thus, in this work, if the chosen financial data is appropriate, then consideration of time-series contribution, location and industry differences is incorporated into the analysis.

Lev [38] applied the decomposition method to a sample of failed and trading firms in order to test its predictive ability. 
TABLE 3: Twenty-four financial ratios selected for the research.

\begin{tabular}{|c|c|c|}
\hline Category & Ratio & Equation \\
\hline \multirow{5}{*}{ Debt-repaying ability } & Inventory turnover in days (average inventory days) & $365 /$ inventory turnover \\
\hline & Interest coverage ratio (times interest earned ratio) & $\begin{array}{l}\text { (Income before taxes }+ \text { interest expense)/interest } \\
\text { expense }\end{array}$ \\
\hline & Current ratio & Current assets/current liability \\
\hline & Acid test ratio (quick ratio) & $\begin{array}{l}\text { (current assets - inventory - advanced } \\
\text { payment)/current liability }\end{array}$ \\
\hline & Accounts receivable turnover in days & 365/account receivable \\
\hline \multirow{8}{*}{ Earning ability } & Earning per share & $\begin{array}{l}\text { (Net income after tax - dividend preferred } \\
\text { stock)/weighted average outstanding shares }\end{array}$ \\
\hline & Return on equity (return on shareholders' equity) & After tax net profit/equity \\
\hline & Profit before tax to paid-in capital & Profit before tax/paid-in capital \\
\hline & Return on sales & After tax net profit/operating income \\
\hline & Return on assets (return on total assets) & $\begin{array}{l}{[\text { After tax net profit }+ \text { interest expense } *(1-\text { tax rate })] /} \\
\text { total assets }\end{array}$ \\
\hline & Gross profit & Sales gross profit/operating income \\
\hline & Operating income to paid-in capital (\%) & Operating income/paid-in capital \\
\hline & Operating profit & Operating profit/operating income \\
\hline \multirow{4}{*}{ Financial structure } & Equity + LT liability to fixed assets & Equity + LT liability/fixed assets \\
\hline & Total liability to total assets (debt ratio) & Total liability/total assets \\
\hline & Equity to total assets & Equity/total assets \\
\hline & Total liability to equity & Total liability/total equity \\
\hline \multirow{7}{*}{ Management efficiency } & Inventory turnover (average inventory turnover) & Operating cost/inventory \\
\hline & Interest to after tax net profit and interest expense & $\begin{array}{l}\text { Interest expenses/[after tax net profit }+ \\
\text { interest } *(1-\text { tax rate })]\end{array}$ \\
\hline & Fixed assets turnover & Operating income/fixed assets \\
\hline & Equity turnover & Operating income/equity \\
\hline & Accounts receivable turnover & $\begin{array}{l}\text { Operating income } /(\text { account receivable }+ \text { note } \\
\text { receivable + other receivable) }\end{array}$ \\
\hline & Operating expense to operating income & Operating expense/operating income \\
\hline & Total assets turnover & Operating income/total assets \\
\hline
\end{tabular}

The assumption being that failed firms have a greater degree of instability in their financial behaviour and therefore the measures of change will be greater than those in the case of the trading ones. His empirical results confirm this. The average decomposition measure was 0.0423 nits in the case of the failed firms whereas the continuing firms had an average of 0.0075 nits. The effectiveness of this method as a predictive tool is further enhanced by dichotomous classification, which demonstrated that he achieved a lower misclassification rate than all other ratio tests by Beaver, except for the cash flow to total debt ratio. The authors have considered whether multivariate predictive ability using accumulative information measures of financial ratios is better than just using the financial ratios model. Access to Taiwanese construction industry data for the empirical study in the investigation is a potential opportunity to apply dynamics to failure prediction. There appears so far to have been relatively little research in this area $[41,42]$. Thus, the question is one that deserves empirical scrutiny. The investigation of predictive ability for business failure is undertaken through the following steps:
(1) a multivariate model which uses financial ratios alone;

(2) transformation of financial ratios to information measures;

(3) a multivariate model which uses the information measures of financial ratios;

(4) comparison of the multivariate predictive ability of financial ratios and the information measures of financial ratios.

The financial ratios selected are listed in Table 3.

\section{Development of the Models}

Three models are developed and tested in this research:

(1) Model d2002: linear discriminant analysis model using financial ratios alone in year 2002;

(2) Model h2002: linear discriminant analysis model using static information measures of financial ratios in year 2002; 
TABLE 4: Failing company data.

\begin{tabular}{lc}
\hline Company name & $\begin{array}{c}\text { First occurrence of } \\
\text { financial crisis }\end{array}$ \\
\hline Kuoyang Construction & $20 / 03 / 99$ \\
Pacific Construction & $16 / 10 / 01$ \\
Bao-Chen Construction Co., Ltd. & $16 / 04 / 02$ \\
Hong Chung Construction & $08 / 09 / 00$ \\
Pao Shiang Construction \& Industrial & $06 / 09 / 02$ \\
Hung Ching Construction & $27 / 12 / 00$ \\
Crowell Development & $28 / 04 / 00$ \\
Ezplace Co., Ltd. & $12 / 01 / 01$ \\
Kee Tai Properties & $29 / 04 / 02$ \\
Sakura Development & $07 / 05 / 02$ \\
Super Max Engineering Enterprise & $12 / 12 / 03$ \\
Tung Wei Construction & $14 / 10 / 03$ \\
Jeou Nien Construction & $19 / 08 / 03$ \\
Sing-Nan Construction & $17 / 09 / 00$ \\
Howang Construction & $02 / 04 / 01$ \\
\hline
\end{tabular}

(3) Model I9702: linear discriminant analysis model using dynamic information measures of financial ratios from year 1997 to year 2002.

Each of these models was used to generate estimated coefficients of independent variables for a particular year. These estimated coefficients were then used to classify firms as failed or nonfailed for the estimation sample. In this research, the discriminant analysis performed uses the STAT module of the SAS statistical software package for this research. This includes the " $t$ "-test, the Shapiro-Wilks " $W$ " test, Wilks' Lambda test, linear discriminant function, and data crossvalidation.

3.1. Selection of Sample Data. The construction industry is a major industry in Taiwan and it has a high percentage $(31.43 \%)$ of company failure. The first step of the data collection was to identify a list of failed firms. The failed set of 15 (the model applied in this research is focused on a financial distress definition and not the juridical definition of failure) failed and excluded companies was drawn from the Market Observation Post System of the Taiwan Stock Exchange Centre (see Table 4). The list is based on the Law of Taiwan Securities and Exchange Act no. 156. Company annual financial statements are derived from the Taiwan Securities and Futures Information Centre for the period of 1997-2002. The acquisition of financial ratio data is from the Taiwan Institute of Economic Research Data Base. The sample is totally focused on Taiwan public construction companies. The sample excludes those companies that had insufficient information in their annual financial reports. The study focused on all those companies failing between 1997 and 2002. The annual financial reports were obtained for failing companies for the five years before failure. If no financial reports could be obtained between 1997 and 2002 for failing companies, they were omitted from the sample.
TABLE 5: The case of non failing companies.

\begin{tabular}{lc}
\hline Company & Established date \\
\hline Continental Engineering Corp. & $29 / 12 / 45$ \\
Kung Sing Engineering Corp. & $01 / 02 / 47$ \\
BES Engineering Corp. & $01 / 09 / 50$ \\
Chien Kuo Construction Co. Ltd. & $21 / 11 / 60$ \\
Delpha Construction Co., Ltd & $28 / 12 / 60$ \\
Da Cin Construction Co., Ltd. & $13 / 02 / 67$ \\
New Asia Construction \& Development Co. & $04 / 12 / 67$ \\
Chain Qui Development Co., Ltd. & $27 / 01 / 73$ \\
Jan-Cheng Construction Co., Ltd. & $03 / 08 / 73$ \\
Prince Housing \& Development Corp. & $20 / 09 / 73$ \\
Chong Hong Construction Co., Ltd. & $04 / 12 / 75$ \\
Farglory Developers Co., Ltd & $09 / 08 / 78$ \\
Kingdom Construction Corp. & $23 / 11 / 79$ \\
Highwealth Construction Corp. & $23 / 01 / 80$ \\
Radium Life Tech. Co., Ltd. & $26 / 03 / 80$ \\
Huang Chang General Contractor Co., Ltd. & $16 / 02 / 81$ \\
Sun-Sea Construction Co., Ltd. & $14 / 01 / 82$ \\
Kedge Construction Co., Ltd. & $13 / 04 / 82$ \\
Long Da Construction Co., Ltd. & $30 / 04 / 82$ \\
Hung Tu Construction Co., Ltd. & $30 / 04 / 84$ \\
Kings Town Construction Co., Ltd. & $13 / 09 / 85$ \\
Yuh Chen United Technologies Corp. & $04 / 11 / 85$ \\
Der Pao Construction Co., Ltd. & $14 / 03 / 86$ \\
Te Chang Construction Co., Ltd. & $20 / 05 / 86$ \\
Hung Sheng Construction Ltd. & $09 / 07 / 86$ \\
Evergreen Construction Co., Ltd. & $22 / 01 / 87$ \\
Sweeten Construction Co., Ltd. & $28 / 11 / 87$ \\
Long Bon Development Co., Ltd. & $22 / 01 / 88$ \\
Huang Hsiang Construction Corp. & $06 / 12 / 91$ \\
Rich Development Co., Ltd. & $30 / 07 / 92$ \\
\hline
\end{tabular}

3.2. Selection of Nonfailed Companies. The nonfailed companies were also drawn from the listed construction companies on the Taiwan Stock Exchange. From 1997 to 2002, there were 24 construction companies that encountered financial distress among the total of 74 listed construction companies. The proportion of nonfailing companies and failing companies is $74: 24$ in that period. This study adopted a $2: 1$ sample (nonfailed companies: failed companies) from the fact that nonfailed companies are always in the higher proportion. This is similar to previous work. In the early 1980s, Taffler [43] used the model (2:1 sample) for forecasting company failure research. In Abidali and Harris's [33] research, they used the sample of 11 failed and 20 nonfailed UK construction companies. Nonfailed companies were selected on a random basis and Table 5 shows the nonfailing companies selected.

3.3. Discriminator Selection. A summary of the financial ratios for the whole sample of companies examined using $t$ statistics, including failed and nonfailed companies, is presented in Table 6. These financial ratios (discriminator) are validated for developing the discriminant models for 
TABLE 6: Descriptive statistics of financial ratios.

\begin{tabular}{|c|c|c|c|c|c|c|}
\hline Ratio & Statistics & Nonfailed & Failed & All & $t$-value & $P>t(\operatorname{sig}<0.05)$ \\
\hline \multirow{4}{*}{ Earning per share } & Mean & 0.5333 & -1.5560 & -0.1632 & 5.8 & $<0.0001$ \\
\hline & Std deviation & 1.4605 & 2.9439 & 2.2926 & & \\
\hline & Skewness & 0.2376 & -1.4377 & -1.7570 & & \\
\hline & Kurtosis & 2.2613 & 2.3136 & 6.0997 & & \\
\hline \multirow{4}{*}{$\begin{array}{l}\text { Total liability to total assets } \\
\text { (debt ratio) }\end{array}$} & Mean & 57.1401 & 63.7699 & 59.3500 & -3.66 & 0.0003 \\
\hline & Std deviation & 12.5984 & 13.2268 & 13.1599 & & \\
\hline & Skewness & -0.5401 & 0.0923 & -0.2444 & & \\
\hline & Kurtosis & 0.8968 & 0.1838 & 0.7970 & & \\
\hline \multirow{4}{*}{$\begin{array}{l}\text { Return on equity (return on } \\
\text { shareholders' equity) }\end{array}$} & Mean & 3.0419 & -22.5108 & -5.4757 & 5.68 & $<0.0001$ \\
\hline & Std deviation & 11.4823 & 38.1211 & 26.7119 & & \\
\hline & Skewness & -0.9749 & -2.0221 & -3.2040 & & \\
\hline & Kurtosis & 2.2006 & 4.9891 & 14.3219 & & \\
\hline \multirow{4}{*}{ Acid test ratio (quick ratio) } & Mean & 37.6841 & 21.1031 & 32.1571 & 4.05 & $<0.0001$ \\
\hline & Std deviation & 34.4809 & 25.7492 & 32.7300 & & \\
\hline & Skewness & 1.2720 & 2.4062 & 1.5235 & & \\
\hline & Kurtosis & 1.4570 & 5.9278 & 2.1300 & & \\
\hline \multirow{4}{*}{$\begin{array}{l}\text { Profit before tax to paid-in } \\
\text { capital }\end{array}$} & Mean & 6.3785 & -16.0643 & -1.1024 & 6.14 & $<0.0001$ \\
\hline & Std deviation & 15.4113 & 29.7033 & 23.7040 & & \\
\hline & Skewness & 0.2328 & -1.3775 & -1.6232 & & \\
\hline & Kurtosis & 1.8243 & 1.9257 & 5.2515 & & \\
\hline \multirow{4}{*}{$\begin{array}{l}\text { Return on Assets (return } \\
\text { on total assets) }\end{array}$} & Mean & 2.3433 & -4.6212 & 0.0218 & 5.94 & $<0.0001$ \\
\hline & Std deviation & 4.4185 & 9.6566 & 7.3905 & & \\
\hline & Skewness & -0.7119 & -1.6213 & -2.1834 & & \\
\hline & Kurtosis & 1.0031 & 3.4162 & 7.7160 & & \\
\hline \multirow{4}{*}{ Operating profit } & Mean & 2.3413 & -33.3269 & -9.5481 & 4.02 & 0.0001 \\
\hline & Std deviation & 15.6043 & 127.9185 & 76.4959 & & \\
\hline & Skewness & -1.6123 & -7.2259 & -11.8351 & & \\
\hline & Kurtosis & 6.2708 & 57.0765 & 158.6935 & & \\
\hline \multirow{4}{*}{$\begin{array}{l}\text { Operating expense to } \\
\text { operating income }\end{array}$} & Mean & 9.1579 & 39.1473 & 19.1544 & -2.58 & 0.0118 \\
\hline & Std deviation & 8.2745 & 100.4341 & 59.8215 & & \\
\hline & Skewness & 2.3242 & 6.9433 & 11.6092 & & \\
\hline & Kurtosis & 7.3203 & 53.6717 & 153.3103 & & \\
\hline
\end{tabular}

this research. Of the 24 selected financial ratios (see Table 3 ), findings from the posttest show that eight ratios outperform other ratios on a statistical basis (see Table 6). These eight ratios could distinguish significantly between nonfailed firms and failed firms. Table 7 thus lists the selected eight financial ratios as discriminator variables for the research. The eight selected financial ratios were used in the construction of the prediction models. These ratios may also be used to evaluate a company's performance.

3.4. Significance of Individual Coefficients. This study used discriminant analysis as a statistical methodology to determine which independent variables are most relevant in assessing failure risk. Applying the $t$-test distinguishes whether the financial ratios are different for nonfailed firms and failed firms. For the selected eight financial ratios for constructing the discriminant model, the variables are significant since the $P$ value is below an $\alpha$-level (statistically significant) of 0.05 . The $F$ test can judge the ability of the discriminator for selected financial ratios. After transforming the $F$ value to the $P$ value, the variable is significant when the $P$ value is below an $\alpha$-level (statistically significant) of 0.05. A more detailed understanding of the relationship can be gained from Table 8 .

In previous research, the ratios shown in Table 9 are considered good discriminators between failed and nonfailed companies. However, in this research, the ratios considered good discriminators between failed and nonfailed companies have the maximum $F$ value and the $P$ value is less than 0.05 . 
TABLE 7: Selection of ratios for the research.

\begin{tabular}{|c|c|c|c|}
\hline \multirow{2}{*}{ Aspect } & \multirow{2}{*}{ Ratios } & \multicolumn{2}{|c|}{ Principle of Judgment } \\
\hline & & Good & Bad \\
\hline Debt-repaying ability & $\begin{array}{l}\text { Acid test ratio (quick ratio): } \\
\text { This is used to test a company's liquidity over a very short } \\
\text { period. It indicates how many of the quick assets can be used } \\
\text { to pay off a short-term loan }\end{array}$ & $\uparrow$ & $\downarrow$ \\
\hline \multirow{5}{*}{ Earning ability } & $\begin{array}{l}\text { Earning per share: } \\
\text { The portion of a company's profit allocated to each } \\
\text { outstanding share of common stock }\end{array}$ & $\uparrow$ & $\downarrow$ \\
\hline & $\begin{array}{l}\text { Return on equity (return on shareholders' equity): } \\
\text { This is the profit resulted by using self-provided capital in a } \\
\text { business year. It is also the profit per dollar of net worth }\end{array}$ & $\uparrow$ & $\downarrow$ \\
\hline & $\begin{array}{l}\text { Profit before tax to paid-in capital (return on capital): } \\
\text { An indicator of the returns on invested capital }\end{array}$ & $\uparrow$ & $\downarrow$ \\
\hline & $\begin{array}{l}\text { Return on assets (return on total assets): } \\
\text { An indicator of earning ability per dollar of the total assets } \\
\text { reflecting the efficiency of overall management }\end{array}$ & $\uparrow$ & $\downarrow$ \\
\hline & $\begin{array}{l}\text { Operating profit: } \\
\text { An indicator of the gross profit of a company or an industry } \\
\text { after marketing and administrative cost is deducted from its } \\
\text { gross profit }\end{array}$ & $\uparrow$ & $\downarrow$ \\
\hline Financial structure & $\begin{array}{l}\text { Total liability to total assets (debt ratio): } \\
\text { This is the rate of loan capital. The bigger the rate, the heavier } \\
\text { its debt will be. The rate would better be not larger than } 0.5\end{array}$ & $\downarrow$ & $\uparrow$ \\
\hline Management efficiency & $\begin{array}{l}\text { Operating expense to operating income } \\
\text { Operating expense comprises marketing and administrative } \\
\text { cost. This ratio tests the efficiency of expense management }\end{array}$ & $\downarrow$ & $\uparrow$ \\
\hline
\end{tabular}

$\uparrow$ the higher the better, $\downarrow$ the lower the worse (debt-repaying and ability, earning ability); $\downarrow$ the lower the better, $\uparrow$ the higher the worse (financial structure and management efficiency).

TABle 8: $P$ value for 3 different models.

\begin{tabular}{|c|c|c|c|c|}
\hline Model & ALL & $\mathrm{d} 2002$ & h2002 & $\mathrm{I} 9702$ \\
\hline Ratio & $P>t($ sig $<0.05)$ & $P>F(\operatorname{sig}<0.05)$ & $P>F($ sig $<0.05$ & $P>F(\operatorname{sig}<0.05)$ \\
\hline Earning per share & $<0.0001$ & 0.0011 & 0.0017 & 0.0035 \\
\hline $\begin{array}{l}\text { Total liability to total assets } \\
\text { (Debt Ratio) }\end{array}$ & 0.0003 & 0.0086 & 0.005 & 0.464 \\
\hline $\begin{array}{l}\text { Return on equity (Return } \\
\text { on shareholders' equity) }\end{array}$ & $<0.0001$ & $<0.0001$ & $<0.0001$ & 0.0144 \\
\hline Acid test ratio (Quick ratio) & $<0.0001$ & 0.0952 & 0.0569 & 0.4511 \\
\hline $\begin{array}{l}\text { Return on capital (Profit } \\
\text { before tax to paid-in capital) }\end{array}$ & $<0.0001$ & 0.0002 & 0.0004 & 0.0053 \\
\hline $\begin{array}{l}\text { Return on assets (Return on } \\
\text { total assets) }\end{array}$ & $<0.0001$ & $<0.0001$ & $<0.0001$ & 0.0009 \\
\hline Operating profit & 0.0001 & 0.0026 & 0.0057 & 0.0034 \\
\hline $\begin{array}{l}\text { Operating expense to } \\
\text { operating income }\end{array}$ & 0.0118 & 0.0048 & 0.0083 & 0.1496 \\
\hline
\end{tabular}

Our discriminators are not consistent with those of Beaver [8] and Abidali [44], as shown by the following:

\section{Return on Assets}

$=\frac{[\text { After tax net profit }+ \text { interest expense } *(1-\text { tax rate })]}{\text { total assets }}$,

$$
=\frac{\text { Operating income }}{\text { paid, in capital }}
$$

Earning Per Share

$$
=\frac{(\text { Net income after tax }- \text { dividend preferred stock })}{\text { Weighted average outstanding shares }} \text {. }
$$

Profit before tax to paid-in capital 
TABLE 9: Ratios used by others.

\begin{tabular}{ll}
\hline Author & Ratio \\
\hline \multirow{3}{*}{ Beaver [8] } & Cash Flow/Total Debt \\
& $\begin{array}{l}\text { Net Income/Total Assets } \\
\text { Total Debt/Total Assets }\end{array}$ \\
\hline \multirow{2}{*}{ Abidali [44] } & Current assets/current liabilities \\
& Net assets/current liabilities \\
& Pre-tax profit/interest \\
\hline
\end{tabular}

These discriminators are not in accord with the results of the previous studies in terms of time, location, industry, and different selected variables.

\section{Construction of the Linear Discriminant Model}

The best discriminating variables are selected according to the maximum $F$ value and where the $P$ value is less than 0.05 , using Wilks' Lambda measures, group discrimination according to the lowest Wilks' Lambda. The linear discriminant model produces a discriminant score $(Z$-score) that overcomes these difficulties. Tables 11-13 show that there is statistical significance in the three models. Discussions on these three models are also given in Sections 4.2, 4.3, and 4.4 respectively.

4.1. Prediction Model with Financial Ratios. The model was developed by selecting financial ratios as independent variables and using discriminant analysis as the statistical methodology. The discriminant function was constructed by utilizing the 45 observations from the estimation sample. These 45 observations were made up from 30 nonfailed firms and 15 failed firms, and each observation consisted of eight financial ratios. The linear discriminant function provided the following prediction model for year 2002.

In this model,

$$
\begin{aligned}
Z= & -17.39693+0.5623 \mathrm{EPS}+0.42995 \mathrm{DR} \\
& +0.07524 \mathrm{ROE}+0.05314 \mathrm{QR}-0.0062 \mathrm{PBTP} \\
& -0.55711 \mathrm{ROA}+0.08262 \mathrm{OP}+0.13057 \mathrm{OEOI},
\end{aligned}
$$

where $Z$ is discriminant score ( $Z$-score); EPS is earning per share; DR is total liability to total assets (debt ratio); ROE is return on equity (return on shareholders' equity); QR is acid test ratio (quick ratio); PBTP is profit before tax to paid-in capital (return on capital); ROA is return on assets (Return on total assets); OP is operating profit; OEOI is operating expense to operating income.

The discriminant coefficient of the linear discriminant model and the associated $F$-statistics are presented in Table 10. When the $P$ value is less than an $\alpha$-level of 0.05 , this shows that the testing of the discriminator variable is significant. That is the discriminator variable could effectively distinguish the failed and nonfailed groups. Also presented in the table is the Wilks' Lambda, which provides an indication of the overall discriminant power for each model, and the $F$ statistics test which shows its statistical significance. If the " $P$ " value is less than an $\alpha$-level of 0.05 , this means that there is a significant discriminant power for the model.

4.2. Prediction Model with Information Measures. Decomposition analysis is a measurement associated with information theory by Shannon [39]. Previous research paid most attention to the decomposition measure in the financial statement $[25,27,29,38,45]$. These researchers thought that financial ratios are a "measure of level." Financial ratios indicate the level of the ratio in a single accounting period. The decomposition measures discussed are "measures of variability." This research explored the transformation of financial ratios to information decomposition measures using information theory. The transformation can adjust the data to be naturally dynamic. Then, accumulative dynamic information measures of financial ratios are compared with static financial ratios model in terms of their failure prediction ability. This new work combines discriminant analysis with the information measures of ratio analysis.

4.3. Prediction Model with Static Information Measures of Financial Ratios. The model was developed by selecting financial ratios as independent variables. The values of these independent variables are normalized for the same basis of measurement. The data are then transformed into the nits of information measures. The transformation equation is:

$$
-K \sum_{i=1}^{m}\left(P_{i}\right) \ln \left(P_{i}\right)
$$

where information unit: 1 bit $=0.693$ nits and 1 nit $=1.443$ bits .

After data transformation, a discriminant function was developed using the discriminant analysis method. The discriminant function was constructed by utilizing the 45 observations from the estimation sample. These 45 observations include 30 nonfailed firms and 15 failed firms, and each observation consisted of eight financial ratios. The linear discriminant function provided the following static information measures prediction model. The model presents discrete information measures for the year 2002. Table 12 lists the other models.

Consider

$$
\begin{aligned}
Z= & -31.27056+451.7909 \mathrm{EPS}-18.0745 \mathrm{DR} \\
& +272.889 \mathrm{ROE}-24.0742 \mathrm{QR}-132.953 \mathrm{PBTP} \\
& -350.049 \mathrm{ROA}+760.2231 \mathrm{OP}-179.198 \mathrm{OEOI},
\end{aligned}
$$

where $Z$ is discriminant score; EPS is earning per share; DR is total liability to total assets (debt rtio); ROE is return on equity (return on shareholders' equity); QR is acid test ratio (quick ratio); PBTP is profit before tax to paid-in capital (return on capital); ROA is return on assets (return on total 
TABLE 10: Difference between discriminant coefficients that subtract non-failure estimates from failure estimates.

\begin{tabular}{|c|c|c|c|c|c|c|c|c|c|}
\hline Model & Constant & EPS & DR & ROE & QR & PBTP & $\mathrm{ROA}$ & $\mathrm{OP}$ & OEOI \\
\hline \multicolumn{10}{|c|}{$\mathrm{d} 2002$} \\
\hline Failure estimates & -17.1094 & 0.5623 & 0.42995 & 0.07524 & 0.05314 & -0.0062 & -0.55711 & 0.08262 & 0.13057 \\
\hline Nonfailure estimates & -13.178 & 0.65988 & 0.41081 & 0.16123 & 0.05599 & -0.08028 & -0.40606 & 0.04412 & 0.06905 \\
\hline Coefficients difference & -3.93132 & 0.09758 & 0.01914 & -0.08599 & -0.00285 & 0.07408 & -0.15105 & 0.0385 & 0.06152 \\
\hline Effected direction & & - & + & - & - & + & - & + & + \\
\hline Comparative influence & & -2 & 4 & -3 & -4 & 1 & -1 & 3 & 2 \\
\hline \multicolumn{10}{|c|}{ h2002 } \\
\hline Failure estimates & -31.2706 & 451.7909 & -18.0745 & 272.889 & -24.0742 & -132.953 & -350.049 & 760.2231 & -179.198 \\
\hline Nonfailure estimates & -40.4299 & 465.8139 & -9.78168 & 355.2129 & -21.6626 & -181.175 & -306.259 & 619.3122 & -15.3504 \\
\hline Coefficients difference & 9.15932 & -14.023 & -8.29279 & -82.3239 & -2.41162 & 48.22137 & -43.7908 & 140.911 & -163.848 \\
\hline Effected direction & & - & - & - & - & + & - & + & - \\
\hline Comparative influence & & -4 & 4 & -2 & 3 & 1 & -3 & 2 & -1 \\
\hline \multicolumn{10}{|c|}{ I9702 } \\
\hline Failure estimates & -3.0053 & -6.90053 & -5.20153 & -50.8526 & 13.08423 & 63.9662 & 4.54677 & 11.10492 & 0.49265 \\
\hline Nonfailure estimates & -0.59522 & 1.37785 & -0.57876 & 9.91085 & 10.49729 & -10.9266 & 0.31489 & 0.36618 & -1.27759 \\
\hline Coefficients difference & -2.41008 & -8.27838 & -4.62277 & -60.7634 & 2.58694 & 74.89277 & 4.23188 & 11.4711 & -0.78494 \\
\hline Effected direction & & - & - & - & + & + & + & + & - \\
\hline Comparative influence & & -2 & -3 & -1 & 4 & 1 & 3 & 2 & -4 \\
\hline
\end{tabular}

EPS: earning per share; DR: total liability to total assets (debt ratio); ROE: return on equity (return on shareholders' equity) QR: acid test ratio (quick ratio); PBTP: profit before tax to paid-in capital (return on capital); ROA: return on assets (return on total assets) OP: operating profit; OEOI: operating expense to operating income.

TABLE 11: Discriminant prediction functions for financial ratios.

\begin{tabular}{|c|c|c|c|c|c|c|c|c|c|}
\hline Year & Constant & $\times 5$ & $\times 9$ & $\times 11$ & $\times 13$ & $\times 14$ & $\times 16$ & $\times 21$ & $\times 22$ \\
\hline Model & & EPS & $\mathrm{DR}$ & ROE & QR & PBTP & ROA & OP & OEOI \\
\hline \multicolumn{10}{|c|}{ d2002 (year 2002) } \\
\hline Failure estimates & & 0.5623 & 0.42995 & 0.07524 & 0.05314 & -0.0062 & -0.55711 & 0.08262 & 0.13057 \\
\hline$F$ value & -17.10935 & 12.27 & 7.57 & 23.24 & 2.91 & 16.56 & 22.07 & 10.18 & 8.85 \\
\hline$P$ value & & 0.0011 & 0.0086 & $<0.0001$ & 0.0952 & 0.0002 & $<0.0001$ & 0.0026 & 0.0048 \\
\hline \multicolumn{10}{|c|}{$\mathrm{d} 2001($ year 2001) } \\
\hline Failure estimates & & -1.24401 & 0.84218 & 0.90864 & 0.2214 & -0.5369 & -1.09293 & 0.63134 & 0.83222 \\
\hline$F$ value & -35.52836 & 12.3 & 3.74 & 12.3 & 4.19 & 13.22 & 11.16 & 8.65 & 8.15 \\
\hline$P$ value & & 0.0011 & 0.0597 & 0.0011 & 0.0467 & 0.0007 & 0.0017 & 0.0053 & 0.0066 \\
\hline \multicolumn{10}{|c|}{$\mathrm{d} 2000($ year 2000$)$} \\
\hline Failure estimates & & 4.84278 & 0.78157 & 0.29487 & 0.15101 & -0.36278 & -0.66894 & 0.04942 & 0.76611 \\
\hline$F$ value & -35.52836 & 12.76 & 1.61 & 12.86 & 2.18 & 13.18 & 12.94 & 13.42 & 23.2 \\
\hline$P$ value & & 0.0009 & 0.2117 & 0.0009 & 0.1469 & 0.0007 & 0.0008 & 0.0007 & $<0.0001$ \\
\hline \multicolumn{10}{|c|}{ d1999 (year 1999) } \\
\hline Failure estimates & & 4.84278 & 0.78157 & 0.29487 & 0.15101 & -0.36278 & -0.66894 & 0.04942 & 0.76611 \\
\hline$F$ value & -32.93814 & 12.76 & 1.61 & 12.86 & 2.18 & 13.18 & 12.94 & 13.42 & 23.2 \\
\hline$P$ value & & 0.0009 & 0.2117 & 0.0009 & 0.1469 & 0.0007 & 0.0008 & 0.0007 & $<0.0001$ \\
\hline \multicolumn{10}{|c|}{$\mathrm{d} 1998($ year 1998$)$} \\
\hline Failure estimates & -30.37234 & 11.26226 & 0.77776 & -1.42688 & 0.13457 & -0.84389 & 3.06178 & 0.03406 & 0.34921 \\
\hline$F$ value & & 7.39 & 0.5 & 6.93 & 2.09 & 8.12 & 8.34 & 7.56 & 13.55 \\
\hline \multirow[t]{2}{*}{$P$ value } & & 0.0094 & 0.4832 & 0.0117 & 0.1555 & 0.0067 & 0.006 & 0.0087 & 0.0006 \\
\hline & Wilks' lambda & $F$ value & $P$ value & & & & & & \\
\hline d2002 (year 2002) & 0.53999348 & 3.83 & 0.0024 & & & & & & \\
\hline d2001 (year 2001) & 0.58099997 & 3.25 & 0.007 & & & & & & \\
\hline d2000 (year 2000) & 0.71613466 & 1.78 & 0.1128 & & & & & & \\
\hline d1999 (year 1999) & 0.57415564 & 3.34 & 0.0059 & & & & & & \\
\hline d1998 (year 1998) & 0.63152791 & 2.63 & 0.0224 & & & & & & \\
\hline
\end{tabular}


TABLE 12: Discriminant prediction function for static information measures.

\begin{tabular}{|c|c|c|c|c|c|c|c|c|c|}
\hline $\begin{array}{l}\text { Year } \\
\text { Model }\end{array}$ & Constant & EPS & $\mathrm{DR}$ & ROE & QR & РВТP & ROA & $\mathrm{OP}$ & OEOI \\
\hline \multicolumn{10}{|c|}{ h2002 (year 2002) } \\
\hline Failure estimates & -31.27056 & 451.7909 & -18.0745 & 272.889 & -24.0742 & -132.953 & -350.049 & 760.2231 & -179.198 \\
\hline$F$ value & & 11.27 & 8.77 & 20.04 & 3.83 & 14.88 & 21.53 & 8.46 & 7.65 \\
\hline$P$ value & & 0.0017 & 0.005 & $<0.0001$ & 0.0569 & 0.0004 & $<0.0001$ & 0.0057 & 0.0083 \\
\hline \multicolumn{10}{|c|}{ h2001 (year 2001) } \\
\hline Failure estimates & -58.96924 & 1608 & -49.0607 & 771.3379 & -68.223 & -536.686 & -630.486 & -1272 & 1646 \\
\hline$F$ value & & 10.47 & 3.89 & 9.75 & 5.23 & 11.62 & 9.87 & 8.44 & 7.49 \\
\hline$P$ value & & 0.0023 & 0.0551 & 0.0032 & 0.0272 & 0.0014 & 0.003 & 0.0058 & 0.009 \\
\hline \multicolumn{10}{|c|}{ h2000 (year 2000) } \\
\hline Failure estimates & -39.73227 & 1416 & 153.7505 & -481.38 & -32.1056 & -521.417 & -555.705 & -3559 & 4542 \\
\hline$F$ value & & 11.23 & 1.32 & 11.79 & 3.35 & 11.39 & 9.62 & 2.28 & 2.4 \\
\hline$P$ value & & 0.0017 & 0.2569 & 0.0013 & 0.0743 & 0.0016 & 0.0034 & 0.1382 & 0.1289 \\
\hline \multicolumn{10}{|c|}{ h1999 (year 1999) } \\
\hline Failure estimates & -14.41437 & -318.759 & 40.17018 & 387.0033 & $-14.8242-$ & -48.2854 & 200.9192 & -30.7025 & 163.9181 \\
\hline$F$ value & & 12.27 & 1.92 & 11.99 & 2.25 & 12.58 & 12.38 & 14.57 & 20.87 \\
\hline$P$ value & & 0.0011 & 0.1727 & 0.0012 & 0.1408 & 0.001 & 0.001 & 0.0004 & $<0.0001$ \\
\hline \multicolumn{10}{|c|}{ h1998 (year 1998) } \\
\hline Failure estimates & -28.33721 & -218.553 & 23.7802 & 592.7827 & 11.38893 & -476.829 & 529.9359 & 225.7035 & 27.49359 \\
\hline$F$ value & & 6.5 & 0.67 & 5.73 & 2.01 & 7.09 & 6.61 & 7.55 & 11.9 \\
\hline \multirow[t]{2}{*}{$P$ value } & & 0.0144 & 0.4183 & 0.0211 & 0.1638 & 0.0109 & 0.0137 & 0.0087 & 0.0013 \\
\hline & Wilks' lambda & $F$ value & $P$ value & & & & & & \\
\hline $\begin{array}{l}\text { h2002 (year } \\
\text { 2002) }\end{array}$ & 0.56752732 & 3.43 & 0.005 & & & & & & \\
\hline $\begin{array}{l}\text { h2001 (year } \\
\text { 2001) }\end{array}$ & 0.590933 & 3.12 & 0.0089 & & & & & & \\
\hline $\begin{array}{l}\text { h2000 (year } \\
2000 \text { ) }\end{array}$ & 0.7350061 & 1.62 & 0.1528 & & & & & & \\
\hline $\begin{array}{l}\text { h1999 (year } \\
\text { 1999) }\end{array}$ & 0.58875486 & 3.14 & 0.0084 & & & & & & \\
\hline $\begin{array}{l}\text { h1998 (year } \\
\text { 1998) }\end{array}$ & 0.6478252 & 2.45 & 0.0316 & & & & & & \\
\hline
\end{tabular}

assets); $\mathrm{OP}$ is operating profit; and $\mathrm{OEOI}$ is operating expense to operating income.

The discriminant coefficient of the linear discriminant model and the associated $F$-statistics are presented in Table 12. If the $P$ value is less than an $\alpha$-level of 0.05 , this shows that the discriminator variable could effectively distinguish between the failed and nonfailed groups. Also presented in the table are the Wilks' Lambda which provides an indication of the overall discriminant power for each model and the F-statistics test, which shows its statistical significance.

4.4. Prediction Model with Dynamic Information Measures of Financial Ratios. The model was developed by considering the selected eight financial ratios as independent variables. These values of independent variables are normalized for the same basis of measurement. Then, the data are transformed to the nits of information measures. The transformation equation is

$$
I_{q}^{p}=\sum_{i=1}^{n} q_{i}\left[\ln \left(q_{i}\right)-\ln \left(p_{i}\right)\right]
$$

Then, using the discriminant analysis, the accumulative information measures are from year 1997 to year 2002:

$$
I_{1997}^{2002}=I_{1997}^{1998}+I_{1998}^{1999}+I_{1999}^{2000}+I_{2000}^{2001}+I_{2001}^{2002} .
$$

The discriminant function was constructed by utilizing the 45 observations from the estimation sample. The linear discriminant function provided the following. The dynamic 
TABLE 13: Discriminant prediction function for dynamic information measures.

\begin{tabular}{|c|c|c|c|c|c|c|c|c|c|}
\hline Year & Conotont & $\times 5$ & $\times 9$ & $\times 11$ & $\times 13$ & $\times 14$ & $\times 6$ & $\times 21$ & $\times 22$ \\
\hline Model & Constant & EPS & DR & ROE & QR & PBTP & $\mathrm{ROA}$ & OP & OEOI \\
\hline \multicolumn{10}{|c|}{ I0102 (years 2001-2002) } \\
\hline Failure estimates & \multirow{3}{*}{-1.77112} & -103.89 & 6.65075 & -667.86 & 2.21077 & 487.6018 & 45.64638 & -153.222 & 296.9721 \\
\hline$F$ value & & 2 & 0.73 & 9.11 & 0.01 & 2.04 & 1.72 & 2.36 & 2.21 \\
\hline$P$ value & & 0.1646 & 0.3989 & 0.0043 & 0.9353 & 0.1602 & 0.1969 & 0.1316 & 0.144 \\
\hline \multicolumn{10}{|c|}{ I0002 (years 2000-2002) } \\
\hline Failure estimates & \multirow{3}{*}{-1.75706} & 14.66382 & 7.29277 & -110.316 & 7.48975 & 99.20083 & -38.0811 & -177.704 & 345.1066 \\
\hline$F$ value & & 4.42 & 0.04 & 2.23 & 0.14 & 3.64 & 4.2 & 4.23 & 4.25 \\
\hline$P$ value & & 0.0414 & 0.8477 & 0.1427 & 0.7145 & 0.0632 & 0.0467 & 0.0458 & 0.0452 \\
\hline \multicolumn{10}{|c|}{ I9902 (years 1999-2002) } \\
\hline Failure estimates & \multirow{3}{*}{-2.07404} & -29.494 & 11.96105 & -158.157 & 3.75704 & 188.3698 & 4.13614 & 7.18328 & 0.92724 \\
\hline$F$ value & & 4.51 & 0.02 & 2.29 & 0.35 & 3.67 & 6.78 & 7.42 & 4.02 \\
\hline$P$ value & & 0.0395 & 0.8812 & 0.1378 & 0.5593 & 0.0621 & 0.0126 & 0.0093 & 0.0512 \\
\hline \multicolumn{10}{|c|}{ I9802 (years 1998-2002) } \\
\hline Failure estimates & \multirow{3}{*}{-2.22264} & -6.11623 & -4.10701 & -48.0587 & 4.81998 & 58.1228 & 3.06783 & 6.68059 & 1.79366 \\
\hline$F$ value & & 6.35 & 0 & 4.08 & 0.21 & 5.92 & 9.57 & 7.2 & 6.13 \\
\hline$P$ value & & 0.0156 & 0.9446 & 0.0496 & 0.6529 & 0.0192 & 0.0035 & 0.0103 & 0.0173 \\
\hline \multicolumn{10}{|c|}{ I9702 (years 1997-2002) } \\
\hline Failure estimates & \multirow{3}{*}{-3.0053} & -6.90053 & -5.20153 & -50.8526 & 13.08423 & 63.9662 & 4.54677 & 11.10492 & 0.49265 \\
\hline$F$ value & & 9.54 & 0.55 & 6.5 & 0.58 & 8.63 & 12.74 & 9.6 & 2.15 \\
\hline \multirow[t]{2}{*}{$P$ value } & & 0.0035 & 0.464 & 0.0144 & 0.4511 & 0.0053 & 0.0009 & 0.0034 & 0.1496 \\
\hline & Wilks' lambda & $F$ value & $P$ value & & & & & & \\
\hline I0102 (years 2001-2002) & 0.57209996 & 3.37 & 0.0056 & & & & & & \\
\hline I0002 (years 2000-2002) & 0.74002174 & 1.58 & 0.1651 & & & & & & \\
\hline I9902 (years 1999-2002) & 0.68296769 & 2.09 & 0.0629 & & & & & & \\
\hline I9802 (years 1998-2002) & 0.64021868 & 2.53 & 0.027 & & & & & & \\
\hline I9702 (years 1997-2002) & 0.54807792 & 3.71 & 0.003 & & & & & & \\
\hline
\end{tabular}

information measures prediction model exhibits accumulative information measures from the year 1997 to year 2002:

$$
\begin{aligned}
Z= & -3.27268-6.90053 \mathrm{EPS}-5.20153 \mathrm{DR} \\
& -50.8526 \mathrm{ROE}+13.08423 \mathrm{QR}+63.9662 \mathrm{PBTP} \\
& +4.54677 \mathrm{ROA}-11.10492 \mathrm{OP}+0.49265 \mathrm{OEOI}
\end{aligned}
$$

where $Z$ is discriminant score; EPS is earning per share; DR is total liability to total assets (debt ratio); ROE is return on equity (return on shareholders' equity); QR is acid test ratio (quick ratio); PBTP is profit before tax to paid-in capital (return on capital); ROA is return on assets (return on total assets); $\mathrm{OP}$ is operating profit; $\mathrm{OEOI}$ is operating expense to operating income.

The discriminant coefficient of the linear discriminant model and the associated $F$-statistics are presented in Table 13. If the $P$ value is less than an $\alpha$-level of 0.05 , this means that there is a significant discriminant power for the model.

\section{Discussion}

This study has been devoted to assessing the worth of a novel failure prediction model for the construction industry. The most important goal for the study was to develop an effective early warning model with a high predictive ability to forecast financial difficulty for construction companies, using a statistical methodology to test whether the results are significant and valid.

The financial ratios that occur most frequently in the literature may not be the most important for model construction because no theoretical or empirical justification exists to indicate that these popular ratios provide an adequate model. Prior research into the selection of the independent variables was not based on a justification or validation of empirical evidence. In this research, the selected variables (eight financial ratios) are found to be statistically significance using the $t$-test.

This research found that "return on assets," "return on capital," and "earning per share" are good discriminators between failed and nonfailed companies. They are not consistent with those of Beaver [8] and Abidali [44].

In Dimitras et al.s [14] and Balcaen and Ooghe's [1] surveys, the discriminant analysis technique was still most 
frequently used in the development of failure prediction models. Discriminant analysis requires certain restrictive assumptions such as multivariate normality and equal covariance, which are often violated. These assumptions are not likely to significantly affect prediction models based on discriminant analysis. The drawbacks of discriminant analysis are the difficulty in interpreting time-series prediction test and the need for a prior probability of failure; however, it is not always easy to find any estimate for the prior probability of failure. Previous discriminant analysis models for business failure prediction, which are not dynamic in nature, have revealed certain weaknesses. Researchers thought of financial ratios as a "measure of level." The information decomposition measures discussed are "measures of variability." Information decomposition measures are dynamic whereas financial ratios are static. The transformation of financial ratios to information decomposition measures using information theory is based on the original model from early studies [38, 45]. The transformation can adjust the data to be naturally dynamic. Therefore, the improved model (Model I9702) had to deal with the time-series contribution in an enhanced way. This model combined discriminant analysis with information measures of ratio analysis to improve the classification accuracy of the prediction model. This model (Model I9702) provides an approach to add dynamic consideration to failure prediction analysis.

The construction industry is a high-risk business. Therefore, it is important to minimize the risk cost by identifying potential failures at the earliest stage. It should be possible to respond quickly to the information which predicts financial failure in order to prevent future contract failure. Use of such methods could aid in contractor selection and help appraise risk better. Prediction models could also be designed to aid auditors, investors, and users in making their assessment of the likelihood of failure or nonfailure.

\section{Further Work and Conclusion}

Overall the approach adopted could serve as the basis for future related studies in different industries or countries. As an extension to this work, it may be possible to use the biostatistics method of survival analysis as an alternative approach to failure prediction for companies classified as at risk in the construction industry. Another possible extension is to build a conceptual framework of dynamic prediction, which applies agent technology developed as a dynamic prediction tool. To help in vetting construction companies on tender lists, it is possible to adopt the models indicated in the research or link these to other machine learning types of prediction methods. Other new methods could also include qualitative variables (such as management variables) that minimize the expected misclassification costs of using these methods.

In conclusion, this research modified discriminant analysis with entropy measures (information measures) derived from financial ratios. The use of discriminant analysis is usually based only on the dichotomous classification of failing and nonfailing groups. The drawbacks of discriminant analysis are the difficulty in interpreting the time-series prediction test and that a prior probability of failure is needed; however, it is not always easy to find any sensible estimate for the prior probability of failure. The estimate for the prior probability of failure is affected by the dynamic circumstances of the economy. This research establishes a way of incorporating this.

\section{Conflict of Interests}

The authors confirm that the work described and the results presented herein have been purely from an academic viewpoint. The authors have no financial interest in the results of the work or in any of the companies providing data to the methodology.

\section{References}

[1] S. Balcaen and H. Ooghe, "35 years of studies on business failure: an overview of the classic statistical methodologies and their related problems," British Accounting Review, vol. 38, no. 1, pp. 63-93, 2006.

[2] R. Kangari, "Business failure in construction industry," Journal of Construction Engineering and Management, vol. 114, no. 2, pp. 172-190, 1988.

[3] R. Kangari, F. Farid, and H. M. Elgharib, "Financial performance analysis for construction industry," Journal of Construction Engineering and Management, vol. 118, no. 2, pp. 349-361, 1992.

[4] J. S. Russell and J. Casey, "Design engineer/contractor bankruptcy: Considerations for debtor and creditors," Journal of Management in Engineering, vol. 8, no. 3, pp. 278-297, 1992.

[5] J. S. Russell, "Contractor failure: analysis," Journal of Performance of Constructed Facilities, vol. 5, no. 3, pp. 163-180, 1991.

[6] R. J. Mason and F. C. Harris, "Technical note: predicting company failure in the construction industry," Proceedings of the Institution Civil Engineers, vol. 66, no. 2, pp. 301-307, 1979.

[7] Z. R. Yang, UK construction company failure prediction : robust heteroscedastic Parzen Window Classifier (BL) [Ph.D. thesis], Portsmouth University, 1997, http://ethos.bl.uk/OrderDetails .do?uin=uk.bl.ethos.310401.

[8] W. H. Beaver, "Market prices, financial ratios, and the prediction of failure," Journal of Accounting Research, vol. 6, no. 2, pp. 179192, 1968.

[9] E. I. Altman, "Financial ratios discriminant analysis and prediction of corporate bankruptcy," Journal of Finance, vol. 23, no. 4, pp. 589-609, 1968.

[10] J. Ohlson, "Financial ratios and the probabilistic prediction of bankruptcy," Journal of Accounting Research, vol. 18, no. 1, pp. 109-131, 1980.

[11] K. Y. Tam and M. Y. Kiang, "Managerial applications of neural networks: the case of bank failure predictions," Management Science, vol. 38, no. 7, pp. 926-947, 1992.

[12] J. E. Boritz and D. B. Kennedy, "Effectiveness of neural network types for prediction of business failure," Expert Systems With Applications, vol. 9, no. 4, pp. 503-512, 1995.

[13] C. Ventura, F. Celimene, R. Nock, and F. Nielsen, "Predicting and interpreting business failures with supervised information geometric algorithms," in Biannual International Conference on Business, Banking and Finance, P. Watson, Ed., UWI, 2011. 
[14] A. I. Dimitras, S. H. Zanakis, and C. Zopounidis, "A survey of business failures with an emphasis on prediction methods and industrial applications," European Journal of Operational Research, vol. 90, no. 3, pp. 487-513, 1996.

[15] G. S. Birrell, "General contractors' management: how subs evaluate it," Journal of Construction Engineering and Management, vol. 111, no. 3, pp. 244-259, 1985.

[16] J. S. Russell and E. Jaselskis, "Quantitative study of contractor evaluation programs and their impact," Journal of Construction Engineering and Management, vol. 118, no. 3, pp. 612-624, 1992.

[17] G. D. Holt, P. O. Olomolaiye, and F. C. Harris, "Factors influencing U.K. construction clients' choice of contractor," Building and Environment, vol. 29, no. 2, pp. 241-248, 1994.

[18] A. A. Bubshait and K. H. Al-Gobali, "Contractor prequalification in Saudi Arabia," Journal of Management in Engineering, vol. 12 , no. 2, pp. 50-54, 1996.

[19] J. S. Russell, Constructor Prequalification: Choosing the Best Constructor and Avoiding Constructor Failure, ASCE, New York, NY, USA, 1996.

[20] S. T. Ng and R. M. Skitmore, "Client and consultant perspectives of prequalification criteria," Building and Environment, vol. 34, no. 5 , pp. 607-621, 1999.

[21] C. H. Wong, G. D. Holt, and P. A. Cooper, "Lowest price or value: investigation of UK construction clients' tender selection process," Journal of Construction Engineering and Management, vol. 18, pp. 767-774, 2000.

[22] Y. I. Topcu, "A decision model proposal for construction contractor selection in Turkey," Building and Environment, vol. 39, no. 4, pp. 469-481, 2004.

[23] J. Pongpeng and J. Liston, "Constractor ability criteria: a view from the Thai construction industry," Construction Management and Economics, vol. 21, no. 3, pp. 267-282, 2003.

[24] M. Hamer, An Investigation of the Usefulness of Information Theory Drived Decomposition Measure in the Prediction of Business Failure, University of Wisconsin-Madison, 1980.

[25] B. Lev, "Decomposition measures for financial analysis," Financial Management, vol. 2, no. 1, pp. 56-63, 1973.

[26] R. Moyer, "Forecasting financial failure: a re-examination," Financial Management, vol. 6, no. 1, pp. 11-17, 1977.

[27] M. C. Walker, J. D. Stowe, and S. Moriarity, "Decomposition analysis of financial statements," Journal of Business Finance and Accounting, vol. 6, no. 2, pp. 173-185, 1979.

[28] M. Pendlebury, "The application of information theory to accounting for groups of companies," Journal of Business Finance and Accounting, vol. 7, no. 1, pp. 105-117, 1980.

[29] P. J. Booth, "Decomposition measures and the prediction of financial failure," Journal of Business Finance and Accounting, vol. 10, no. 1, pp. 67-82, 1983.

[30] P. Booth and P. Hutchinson, "Distinguishing between failing and growing firms: a note on the use of decomposition measure analysis," Journal of Business Finance and Accounting, vol. 16, no. 2, pp. 267-271, 1989.

[31] M. Tamari, "Financial ratios as a means of forecasting bankruptcy," Management International Review, vol. 6, no. 4, pp. 15-21, 1966.

[32] R. J. Taffler and H. J. Tisshaw, "Going Going gone four factors which predict," Accountacy, vol. 88, pp. 50-54, 1977.

[33] A. F. Abidali and F. Harris, "A methodology for predicting company failure in the construction industry," Construction Management and Economics, vol. 13, pp. 189-196, 1995.
[34] G. Severson, J. Russell, and E. Jaselskis, "Predicting contract surety bond claims using contractor financial data," Journal of Construction Engineering and Management, vol. 120, no. 2, pp. 405-420, 1994.

[35] C. Zavgren, "Assessing the vulnerability to failure of American industrial firms: a logistic analysis," Journal of Business Finance and Accounting, vol. 12, no. 1, pp. 19-45, 1985.

[36] K. Keasey and P. Mcguinness, "The failure of UK industrial firms for the period 1976-1984, logistic analysis and entropy measures," Journal of Business Finance \& Accounting, vol. 17, pp. 119-135, 1990.

[37] P. Barnes, "The analysis and use of financial ratios: a review article," Journal of Business Finance and Accounting, vol. 14, no. 4, pp. 449-461, 1987.

[38] B. Lev, "Information, entropy and the aggregation problem in financial statements," in Accounting and Information Theory, chapter 2, American Accounting Association, Miami, Fla, USA, 1969.

[39] C. E. Shannon, "A mathematical theory of communication," Bell System Technical Journal, vol. 27, pp. 379-423, 1948.

[40] J. Argenti, Corporate Collapse: The Causes and Symptoms, McGraw Hill, London, UK, 1976.

[41] T. Y. Hsieh and M. H. L. Wang, "Financial evaluation of Taiwan's property development industry," in International Conference on Construction Information Technology, pp. 678-696, 2000.

[42] T. Y. Hsieh and M. H. L. Wang, "Finding critical financial ratios for Taiwan's property development firms in recession," Logistics Information Management, vol. 14, no. 5-6, pp. 401-413, 2001.

[43] R. J. Taffler, "Forecasting company failure in the UK using discriminant analysis and financial ratio data," Journal of the Royal Statistical Society, vol. 145, no. 3, pp. 342-358, 1982.

[44] A. F. Abidali, A methodology for predicting company failure in the construction industry [Ph.D. thesis], Loughborough University of Technology, Loughborough, UK, 1990.

[45] H. Theil, Economics and Information Theory, Rand McNally, Chicago, Ill, USA; North Holland, Amsterdam, The Netherlands, 1967. 


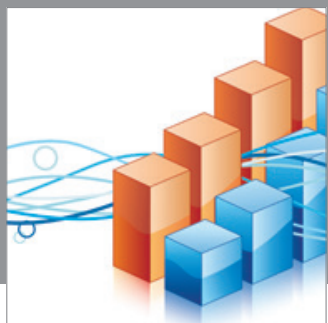

Advances in

Operations Research

mansans

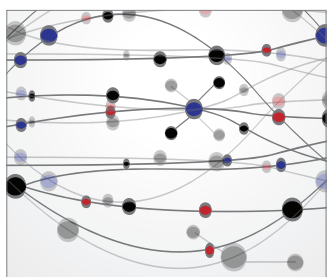

The Scientific World Journal
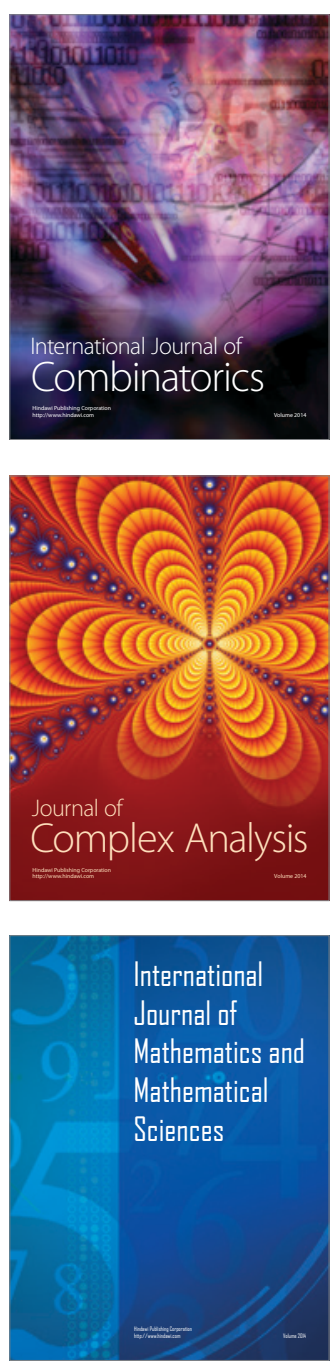
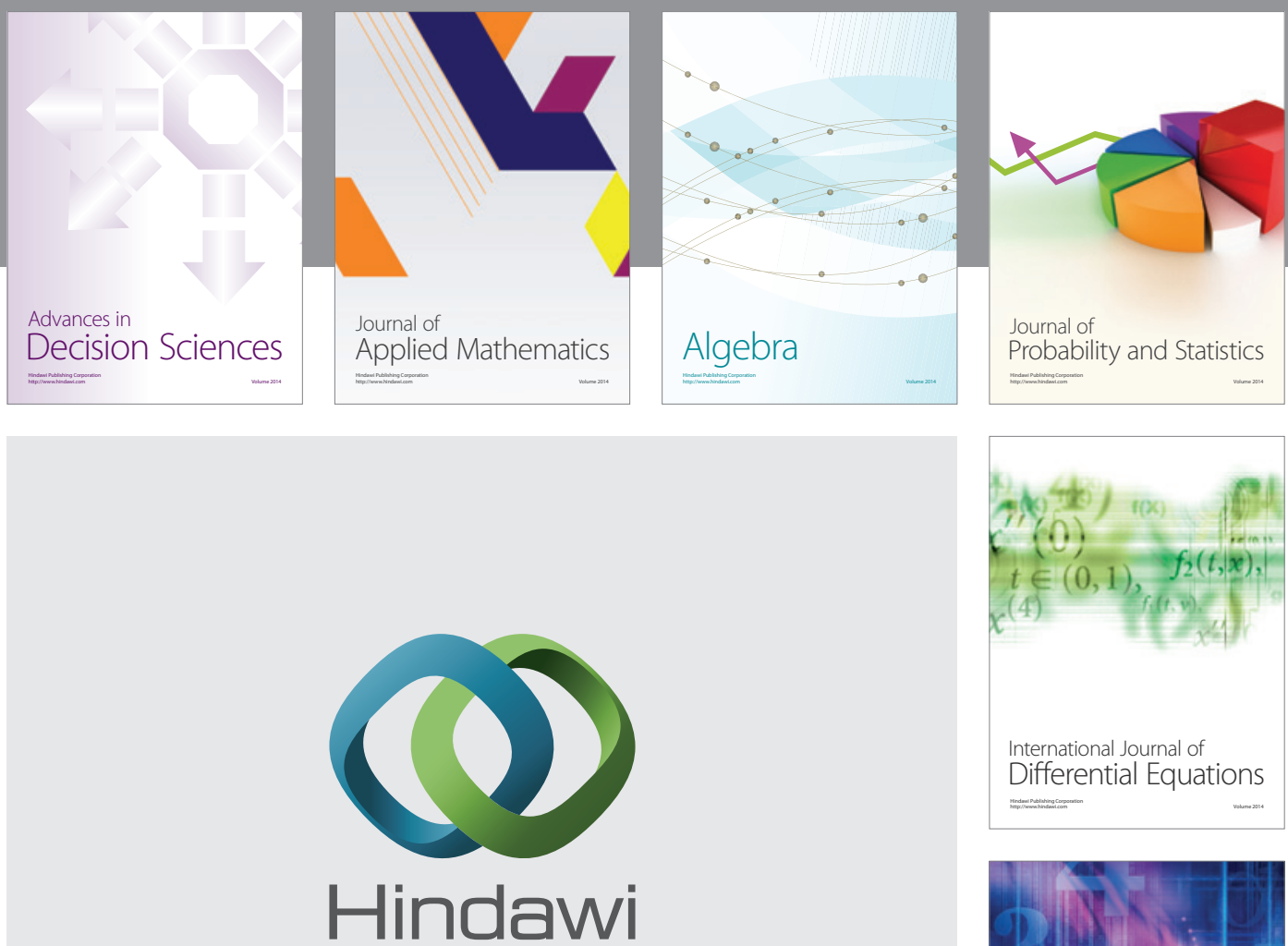

Submit your manuscripts at http://www.hindawi.com
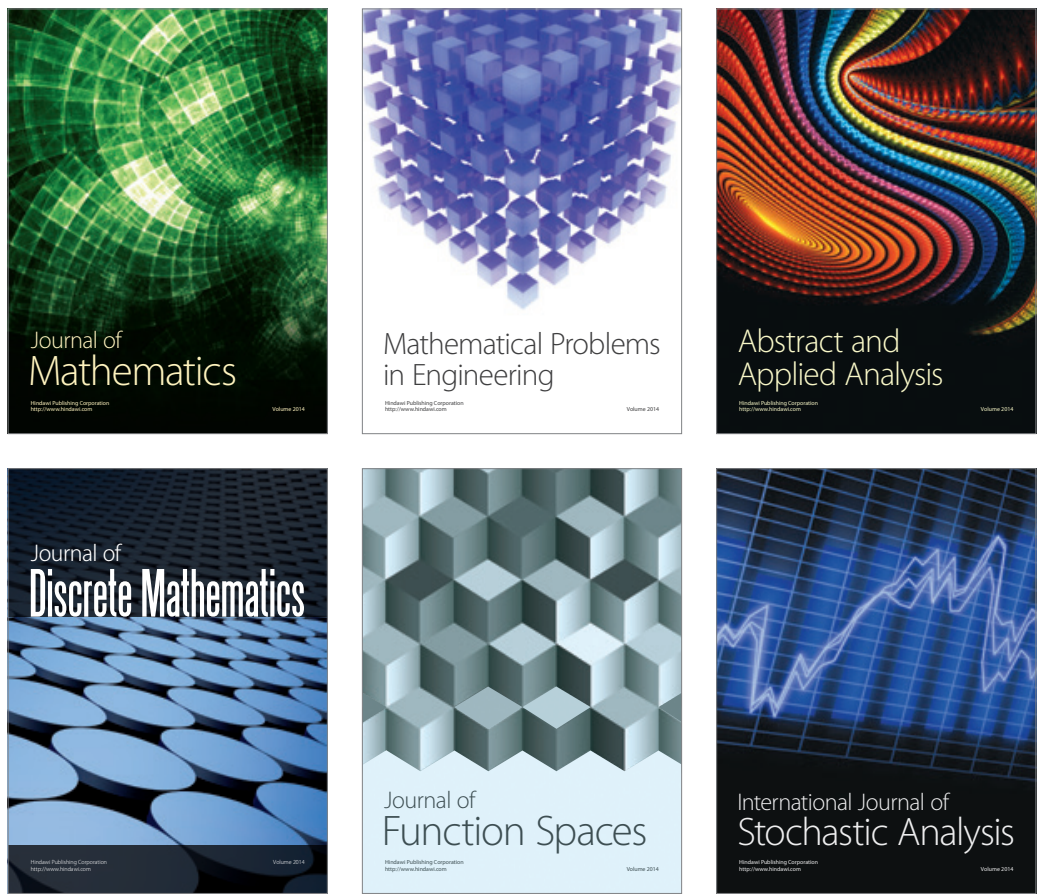

Journal of

Function Spaces

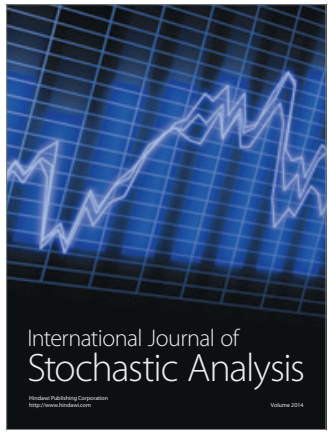

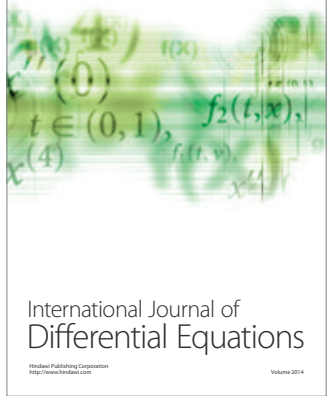
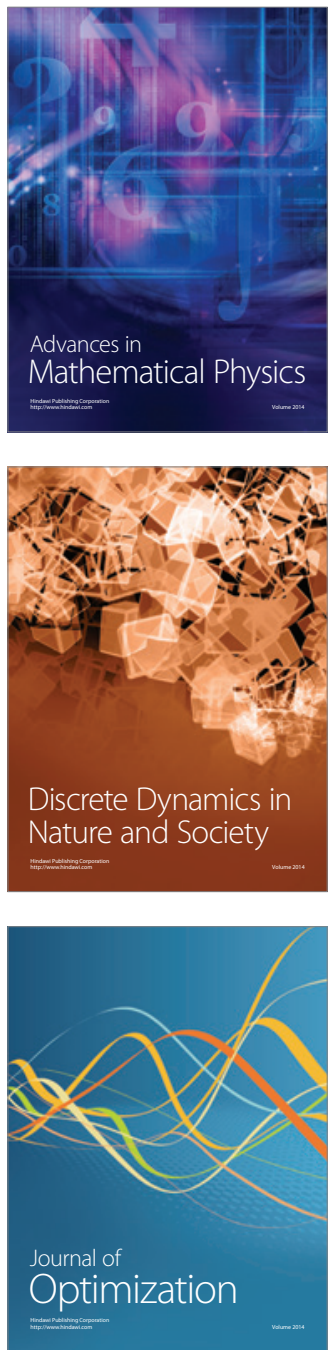